\title{
Agriculture and food security under climate change in Nepal
}

\begin{abstract}
Nepal is amongst the poorest countries worldwide, and its varied topography and social vulnerability make the country particularly susceptible to climate change. In turn, Nepal has low adaptive capacity to respond to the variability due to climate change. Small scale (average $0.7 \mathrm{ha}$ ), subsistence agriculture is the mainstay of Nepal's economy, employing $78 \%$ of work force, and contributing nearly $36 \%$ of Nepal's GDP. Only $27 \%$ of agricultural land has access to irrigation, whereas the great part of arable land is rain-fed. Recent climate change in Nepal has demonstrably impacted crop productivity. The question thus arises whether present and perspective climate change will negatively impact agriculture, and food security. In spite of such, few studies recently explored future impact of climate change specifically on Nepal's food security. Here I summarize, and critically comment the available literature about recent and perspective impact of climate change on Nepal's agriculture, and rural economy, highlight the main findings and criticalities, and I suggest future directions of investigation.
\end{abstract}

Keywords: climate change impacts, crop yield, food security, Nepal
Volume 6 Issue 6 - 2017

\author{
Bocchiola D 1,2 \\ 'Department ICA, Politecnico di Milano, Italy \\ ${ }^{2}$ EVK2-CNR Association, Italy
}

Correspondence: Bocchiola D, Politecnico di Milano, L. Da Vinci, 32, 20I33, Milano, Italy, Email daniele.bocchiola@polimi.it

Received: March 29, 2017 | Published: April 04, 2017

\section{Introduction}

Agriculture is heavily impacted worldwide by climate change, and yield reduction may result in the decline of food security, especially in mountainous areas. ${ }^{1-4}$ Agriculture requires much water for irrigation, and worldwide roughly $70 \%$ of the water is used by agriculture, ${ }^{5-7}$ and increasingly so under population growth pressure. ${ }^{8}$ Most relevant crops for food security are cereals, and especially wheat, Triticum L., maize Zea Mais L., and rice Oryza L. ${ }^{9-12}$ requiring significant amounts of water for production, i.e. rainfall and often irrigation during summer or dry season. ${ }^{13,14}$ Under climate change the need of water for cropping may increase, requiring adaptation strategies. ${ }^{11,13}$ Effects of climate on agriculture may include

i. $\mathrm{CO}_{2}$ increase on plant respiration cycle, especially for plants of type $\mathrm{C} 3$, and less for type $\mathrm{C} 4,{ }^{15-17}$

ii. effects of temperature and rainfall changes. ${ }^{18}$ Climate change as projected for the 21 st century may significantly alter crop production. ${ }^{19,20}$

The recently issued assessment report 5 AR5 of the Intergovernmental Panel on Climate Change IPCC states that negative impacts of climate trends have been more common than positive ones worldwide, ${ }^{21}$ and there are between 5 and 200 million additional people at risk of hunger within $2100 .^{1,22,23}$

This review focuses on present, and prospective impact of climate change on agriculture, and food security of Nepal. With an estimated GDP of $\$ 562$ per capita in 2012, Nepal is ranked amongst the poorest countries worldwide, and displays $25 \%$ of population below poverty line of $\$ 1.25$ per day. ${ }^{24}$ In spite of the large supply of freshwater from the Himalayas. ${ }^{25,26} 28 \%$ of the population is thought not to have access to safe drinking water. Small scale (average $0.7 \mathrm{ha}$ ), subsistence agriculture is the mainstay of Nepal's economy, employing $78 \%$ of work force, and contributing nearly $36 \%$ of Nepal's GDP, ${ }^{27}$ with however $60 \%$ of the population being undernourished, especially in the mountain areas. ${ }^{28}$ Due to lack of investment capacity and infrastructure as well as lack of market opportunities, the majority of poor peasants adopt traditional technology in their production system, ${ }^{29}$ and it is estimated that hardly $13 \%$ of the agricultural products are traded in the market. ${ }^{30}$ Approximately $17 \%$ of the total land area of Nepal is agricultural, ${ }^{24}$ but only $27 \%$ of such agricultural land has access to irrigation, and it is located above all in the Terai zone (the southern, more fertile belt along the Nepal-India border), whereas the great part of arable land is rain-fed. Rice single cropping is feasible up to $2200 \mathrm{~m}$ a.s. 1 . or so, while double cropping is generally limited to areas below $1000 \mathrm{~m}$ as. $1 .^{4}$ Maize can be successfully cultivated at altitudes up to $2800 \mathrm{~m}$ a.s.1. but in practice, maize cultivation is largely limited below $2500 \mathrm{~m}$ a.s.1. $1^{4,31}$ Wheat is cultivated up to altitudes of $3000 \mathrm{~m}$ a.s.1. $1^{4,31}$ Nepal's varied topography and social vulnerability make the country particularly susceptible to climate variations,,$^{24,32-38}$ and the country has low adaptive capacity to respond to crop variability under climate change. ${ }^{39}$ The effect of recent climate change in Nepal includes rapid temperature increase, $3,34,40$ erratic rainfall pattern, decreased length of winter, and increased frequency and length of droughts. ${ }^{41}$ Therefore, the question arises whether present and perspective climate change will impact cropping, and food security. The scope of this brief review is thus twofold, namely to

i. summarize the available knowledge concerning present, and prospective impact of climate change upon agriculture, and food security in Nepal, including objective measures, and social perception, and

ii. Delineate open issues, and future avenues of investigation. In the forthcoming, I first analyze the available literature focusing upon present and future climate change effects on agriculture of Nepal, and possibly related socio-economical issues. Albeit water resources and hydrology are generally speaking related to crop production via irrigation, and water footprint concepts, I will only 
consider manuscripts specifically focusing on climate change, and subsequent impact on crops, and food security, while more general contributions tackling water resources management will not be analyzed. Also, I will report some studies concerning perception of climate change impact. Second, based on this review exercise, I will discuss open issues and critical aspects, and suggest potential avenues for future endeavor.

\section{How climate change affects food security of Nepal?}

\section{State of the art on climate change impact in Nepal}

Among others, Karki et al., ${ }^{24}$ discuss impact of climate change on Nepali agriculture. Also based on, ${ }^{29,42}$ they suggest that impact of climate change is expected to be severe in the mountain and Himalayas, as compared to plain areas. In the highest altitudes, population entirely relies on agriculture for their subsistence, and the extreme climatic conditions will put these areas in economic stress by affecting the agricultural production and food security. They accordingly provide a ranking of Nepal's districts according to overall climate change vulnerability, from very low to very high. They report that in the wake of a rain deficit in the eastern part of Terai during the year $2005 / 06$, and that crop production reduced by $12.5 \%$ on national basis. On the other hand, torrential rain occurring in the mid western Terai reduced crop production by $30 \%$ in the same year. Bhatt et al. ${ }^{4}$ investigated crop yield under historical climate (1967-2008) for rice, maize and wheat in the Koshi basin (Solukhumbu district), finding significant impact of growing season temperature and precipitation on crop production in the region. Rice, maize and wheat, cultivated below 1100,1350 and $1700 \mathrm{~m}$ a.s.l. respectively, suffer from stress due to high temperatures. The response of crop yields to a unit rise of temperature in growing season varies from -6 to $+16 \%,-4$ to $+11 \%$ and -12 to $+3 \%$ for rice, maize and wheat, respectively, depending on elevation. Mostly they found warming trends in the growing season mean temperatures, with clear evidence of negative impacts on yields. However, they observed positive impacts of warming at some high elevation areas, for rice and maize. They conclude that whenever the observed temperature trends would continue in future, the impact would be mostly negative on crop production, but crop production may still gain from warming at relatively higher altitudes provided other conditions are favorable. Poudel et al., ${ }^{43}$ empirically studied the impact of climate on yield of rice, and wheat in central Nepal (16 districts with 17 years of data) focusing on seasons, and altitudes. The employed a stochastic approach driven by wise climatic and geographical variables. Their result show that an increase in the variability of temperature and rainfall has adverse effects on crop productions. On the other hand, change of temperature and rainfall may become beneficial, harmful or negligible, depending on the altitudes and the crops. Accordingly, adaptation strategies must be tailor-made considering growing seasons, altitudes and the crops.

\section{Perception and adaptation to climate change in Nepal}

Among others studies related to agriculture of Nepal under global warming ${ }^{44,45}$ Dulal et al., ${ }^{39}$ used data collected through survey interviews to infer the ability of the poor to adapt to climate change. They focused on the area of Koshi Tappu river floodplain, in the Southern most part of Nepal, where they carried out repeated interviews find out how recurring extreme climatic events (e.g. floods) over the years had impacted livelihoods, and if people had the required capital assets to remain resilient in the face of climateinduced extreme events. They concluded that increased extreme event frequency, and magnitude are impacting heavily the physical capital of the poor, largely including farmlands and crops, so abating the potential for resilience in the wake of disasters. They suggest that although the government of Nepal has fostered agencies with the mandate of informing and assisting in flood related issues, generally low level of education of land owners and farmers may make such effort little successful. Targeted educational programs may help farmers to access information on potential adaptation measures, including choice of different crops type, flood resistant seeds, planting times, crop rotation and soil conservation. Manandhar et al., ${ }^{46}$ used an array of tools to gather perceptions of, and adaptations to climate change by farmers, in two different ecological regions of Nepal, Terai (lowland), and the mountains. They conclude that

\section{i. Most farmers perceive climate change acutely, especially in terms} of increasing temperature, and

ii. they respond to it with adaptations at an individual level. They suggest however that farmers may be capable of responding to climate change, but their adaptation measures are mostly short term, and may be inadequate to cope with long term modifications of the climate. Innovative micro-insurance schemes can be another tool to help Nepalese small-holder farmers to cope with climate variability and change, similarly to what done e.g. in Africa. ${ }^{47}$

Gentle et al ${ }^{48}$ used participatory social research methods together with climate vulnerability and capacity analysis (CVCA) to carry out a study in the mountainous Jumla District in Northern Nepal. They explored

\section{i. How climate change affects livelihood of local communities, and}

ii. how different wellbeing groups are differentially impacted. They found that under recently increased temperature and more erratic rainfall, a general trend of decreasing crop yield occurred, however with difference between different social groups. The poorest households claimed they did not grow rice three years in a row as they only owned rain-fed land. Well-off and medium households also reported losing rice cultivation in rain-fed land, but they continued rice production every year from their permanently irrigated land.

Also, well-off households reported

i. Vegetable farming as a crop diversification strategy, and

ii. selling non-irrigated lands and buying irrigated lands to secure their crops. Changing weather patterns eventually led to resource degradation, food scarcity, lack of basic services, and increasing social inequalities.

Chhetri et al., ${ }^{49}$ used the case study of Nepal to illustrate how farmers and supporting institutions can develop climate sensitive technologies. They conclude that Nepal has developed a multilevel institutional partnership between policy makers, scientists, farmers, and other non-governmental organizations in recent years. This partnership improved knowledgenetwork among institutions, scientists and farmers and enabled them to seek site specific technologies (e.g. innovation of rice varieties, development of appropriate agronomic practices) that are effectively responsive to climate changes. 


\section{Projected impacts of climate change during XXI century}

\section{A global perspective}

Global studies covering food security issues under future climate have been developed, that can be used to set the context about Nepal's situation with respect to the broader picture. Rosenzweig et al., ${ }^{50}$ produced possibly the first global assessment of the potential impacts of climate change scenarios on crops. They used numerical crop models for wheat, rice, maize, and soybeans to simulate yields at 112 locations in 18 countries under climate change using the output of three climate models, and then scaled-up to country level pointbased estimates of change. They found that enhanced concentrations of atmospheric $\mathrm{CO}_{2}$ may increase the productivity of most crops through increasing the rate of leaf photosynthesis and improving the efficiency of water use. Rosenzweig et al., ${ }^{50}$ showed a large degree of spatial variation in crop yields across the globe, and both the sign and magnitude vary with different climate models and from one country to another. Their study, ${ }^{50}$ subsequently updated by World Bank ${ }^{51}$ indicated in Nepal a relative change in (cumulative) crop yield at 2050 in the order of $-10 \%$ to $-15 \%$ against present. Wheeler et al., ${ }^{23}$ recently reviewed the findings in global food security, by commenting that crop yields are more negatively affected across most tropical areas than at higher latitudes, and impacts become more severe with increasing climate change. They notice that large parts of the world with expectedly decreasing crop productivity under climate change, coincide with countries currently having high level of hunger. Review of changes in the yield of major crops in South Asia under climate change displayed that crop yield may decline by $-8 \%$ by $2050,-16 \%$ for maize, and $-11 \%$ for sorghum. No large change in yield was detected for rice.

\section{Projected impacts of climate change in Nepal}

Focusing more locally, some recent studies are also available for Nepal, targeting potential evolution of climate until 2100 or so, and subsequent fallout upon agriculture, and food security. Agrawala et al., 52 examined the results of the OCDE Development and Climate Change project for "Development and climate change in Nepal: focus on water resources and hydropower", where climate change scenarios (until 2100) for the entire Nepal were assessed, using MAGICC/SCENGEN suite of 7 best performing (out of 17) GCM models (B2 SRES). They found a projected change of average yearly temperature (against 1977-1994) in the order of $+1.7^{\circ} \mathrm{C}$ until 2050 and of $+3.0^{\circ} \mathrm{C}$ until 2100. Precipitation changes in $^{52}$ were $+7.3 \%$ until 2050 and $+12.6 \%$ until 2090, with large deviations from one another model. Karmacharya et al., ${ }^{53}$ projected Nepal climate under A2 SRES scenario until 2070, and found an increase (vs 1961-1990) of temperature of $+1.9^{\circ} \mathrm{C}$ yearly, +2.1 in winter, and $+1.9^{\circ} \mathrm{C}$ in monsoon season. Lamsal et al., ${ }^{54}$ used the CSM-CERES-Rice model to evaluate the sensitivity to climate change (weather years, $\mathrm{CO}_{2}$, max and min temperatures, solar radiation) on rice production in Chitwan, with humid sub-tropical climate, and found that temperature is a most sensitive parameter for yield. Amgain ${ }^{54}$ used CSM-CERES-Maize to model, and subsequently project until 2080 maize yield (4 genotypes), again in Chitwan. Using different climate change scenarios from IPCC (AR4) for 2020, 2050 and 2080 to fix reference changes in CO2 (370$570 \mathrm{ppm}$ ), max and min temperatures, and solar radiation, they found that there would be an increment (up to $+15 \%$ ) in winter maize yield until 2020, and subsequent drastic yield loss in 2050 (down to -10\%) and 2080 (down to $-42 \%$ ), under present management. Palazzoli et al., ${ }^{31}$ investigated the effect of prospective climate change (until 2100 ) on hydrology and productivity of rain-fed crops (wheat, maize, rice) in the Indrawati river basin (623-5854m a.s.1.), $50 \mathrm{~km}$ NorthEast of Kathmandu. They used climate scenarios from 3 climate models (CCSM4, EC-Earth, ECHAM6), each one under 3 different representative concentration pathways (RCPs) and the Soil and Water Assessment Tool (SWAT) model to estimate modified crop yield at half century (2045-2054) and end of century (2085-2094), against a control run decade (1995-2004). At half century they find increased temperature yearly from $+0.6^{\circ} \mathrm{C}$ to $+2.3^{\circ} \mathrm{C}$ (min with RCP2.6, max with RCP8.5), and from $+1.4^{\circ} \mathrm{C}$ to $+2.4^{\circ} \mathrm{C}$ in monsoon season. At the end of century, they projected from $+0.7^{\circ} \mathrm{C}$ to $+6.2^{\circ} \mathrm{C}$ (min with RCP2.6, max with RCP8.5) yearly, and from $+1.1^{\circ} \mathrm{C}$ to $+4.8^{\circ} \mathrm{C}$ in monsoon season. Precipitation displays more erratic patterns. Palazzoli et al., ${ }^{31}$ found on average $-41.6 \%$ in Winter, $+15 \%$ in Summer, and $+9.5 \%$ yearly, but with CCSM 4 providing large increase in summer, and fall (thence, yearly). Considering only EC-Eearth, and ECHAM6, they found $-54 \%$ in winter, $-5 \%$ in summer, and $-17.3 \%$ yearly. Crop changes in Palazzoli et al., ${ }^{31}$ display some variability, and complex vertical structure. Basin average rice yield is basically projected to increase $(+5.7 \%$ on average at $2050,+3.0 \%$ on average at 2100$)$, with however large variability for different scenarios $(+2 \%$ to $+12.1 \%$, and $-17.0 \%$ to $+9.1 \%$, respectively), with somewhat large year to year coefficient of variation $\mathrm{CV}$, an indication of decreased food security. Maize yield would largely decrease $(-2.8 \%$ on average at $2050,-3.5 \%$ on average at 2100$)$, with however large variability $(-15.0 \%$ to $+4.7 \%$, and $-17 \%$ to $+4.0 \%$, respectively), and again large $\mathrm{CV}$. Wheat would be seemingly the most impacted crop $(-3.6 \%$ on average at $2050,-0.1 \%$ on average at 2100 ), with very large spread $(-35.6 \%$ to $+13.2 \%$, and $-25.1 \%$ to $+18.0 \%$, respectively), and very large $\mathrm{CV}$ in all simulations. The authors attributed modified crop patterns mostly to

i. Increased $\mathrm{CO}_{2}$, possibly leading increase of biomass especially in C3 plants,

ii. larger potential for thermal stress, shortening growth season, and increasing year to year variability, and

iii. erratic rainfall patterns, changing year to year water supply. Visibly, large uncertainty is attached to projections of future crop yield, albeit the large variation reported mirror substantially low yields on average (i.e. ca. 2.8 tonha-1, 2.5 tonha-1, and 1.7 tonha-1 for rice, maize, wheat, respectively, very low as compared with other areas worldwide, e.g. 13, 55). However, the finding that more erratically changing temperature (heat waves) and rainfall (wet/dry spells) cascades into more variable (insecure) food production is consistent with the findings reported above.

\section{Open issues and avenues for research}

From the discussion above, one can highlight a number of open scientific issues that need be tackled to guide effective adaptation of Nepali agriculture against climate change and of related research avenues as follows.

\section{Lack of knowledge of present and future climate change impact on agriculture}

Not yet exhaustive know how is available of the impact of present climate change upon agriculture, crop yield, and its vertical structure. 
Nepal still lacks strong scientific data climate change, and due to varied geographical setting sufficient meteorological data cannot be easily obtained from remote parts of the country. ${ }^{24}$ This has so far reduced to a few the studies tackling such issue, and more investigation is required. Even more pressing is the need for developing scenarios of crop yield in the future, under diverse climate scenarios, as provided by IPCC, and other credible sources. Especially important is to explore scenario uncertainty, so as to provide guidelines for adaptation based on what if scenarios and iterative improvement based upon climate evolution. Few studies are available that the author here could find tackling prospective impact of climate change and those are limited to specific areas. Locally tailored investigation is needed to correctly assess prospective crop systems' evolution in different areas, and subsequent upscaling may be done at the country scale. Such studies should in principle provide a base for brainstorming, identifying, and testing of adaptation measures, to be then proposed to policy makers for implementation. It needs be stressed that complex topography of Nepal makes more complicate data gathering, field monitoring and implementation of solutions. Solution based upon Crowd Science ${ }^{56}$ may allow the local people to help in data retrieval, implementation, observation, while involving actively the local communities in problem solving, and design of alternatives.

\section{Need for large scale planning and developing of irrigation schemes, and hydropower plants}

Clearly, a lack of irrigation schemes makes cropping largely insecure in Nepal under climate warming. Scientific effort should be devoted to investigate water demand for target crop yield under planned population increase, and to assess water resources availability. Accordingly, irrigation schemes may be developed to carry water from the zone of production, i.e. largely in the high altitudes of the Himalayas, to cropped areas at lowest altitudes. In this respect, one notices that Nepal has large water availability, and tremendous need also for hydropower energy. It is estimated that only $20 \%$ of Nepali population has access to electricity, and 5\% in the rural areas. Only $1-3 \%$ of energy demand in Nepal comes through hydropower, ${ }^{57}$ while instead large wood burning is used (ca. 66\%), together with crop biomass (ca. 15\%), and dried animal waste for heating in the valleys (ca. 8\%), plus imported fuels (ca. 8\%). ${ }^{58,59}$ Recent estimates carry a potential for hydropower nearby $40-60 \mathrm{GW},{ }^{60-62}$ with ca. 600 MW produced nowadays, mostly run-of-river. Accordingly, Nepal needs to tackle soon enough joint management of its large amount of water for hydropower production and irrigation. Again, here shared solutions need to be chosen and implemented with involvement of local stakeholders at all possible levels, and science can provide tremendous added value to technological solutions.

\section{Cropland planning under a science driven approach}

Modified climate will carry to modified proficiency of crops with altitude, as largely demonstrated in the present literature. Accordingly, future land use planning, specifically for colonization of mountain areas for cropping, already largely ongoing as driven by population dynamics, and market economy ${ }^{63,64}$ should follow rationale principles, including optimized crop yield as a function of altitude under climate change. Scientists therefore need to develop crop scenarios including evolving land use change according to properly developed models against past observations

\section{Need for institutional support}

As reported, recently in Nepal partnerships between policy makers, scientists, farmers, and other non-governmental organizations helped in developing adaptation. In order to respond to climate change, the government of Nepal created a National Adaptation Programme of Action (NAPA), a multidisciplinary platform of information, data and studies on climate change, usable to identify priority activities. ${ }^{24}$ Nepal does not have enough funds to invest on activities focused on reducing the impacts of climate change, and heavily relies upon donors' support, being such lack bottlenecks for agriculture sector in Nepal. ${ }^{65,66}$ Accordingly therefore adaptation to climate change seems mostly based nowadays on an individual, or community based level, and one wonders whether such attitude will be sufficient on the long term, with worsening of global change. Also, climate change impacts more the poorest, less resilient people, more likely living on subsistence and rain fed cropping, while well-off communities may apply adaptive strategies. Scientists need to be working towards developing scientific based, and yet feasible solutions to support adaptation strategies valid on the long run.

\section{Conclusion}

Present and future impact of climate change upon life and economy of Nepal neither is exactly measurable nowadays, nor can be predicted quantitatively with large accuracy. Yet, it is sure that modified weather will influence hydrological cycle, glaciers' down wasting, floods and droughts patterns for the year to come, and food security in many ways. I here proposed a short review of the recent state of the art concerning direct impact of climate on crop production, and subsequently on food security. Nepal is heavily vulnerable to climate change for geographical, social, and economical reason, including lack of own resources, and energy, and the need for support from foreign donors. Large share of the population relies upon agriculture for subsistence, being thus the fate of economy, and food security of people at the mercy of weather, and getting worse under ongoing climate change. Much effort must be devoted to understand the future of climate and agriculture, and to profit of the large amount of water available from the mountains to boost crop production in the mountains, and hydropower production.

\section{Acknowledgements}

None.

\section{Conflict of interest}

The author declares no conflict of interest.

\section{References}

1. Olesen JE, Bindi M. Consequences of climate change for European agricultural productivity, land use and policy. European Journal of Agronomy. 2002; 16:239-262.

2. Parry ML, Rosenzweig C, Iglesias A, et al. Effects of climate change on global food production under SRES emissions and socio-economic scenarios. Global Environ Change. 2004;14:53-67.

3. Malla G. Climate change and its impact on nepalese agriculture. The Journal of Agriculture and Environment. 2008;9:62-71.

4. Bhatt D, Maskey S, Babel MS, et al. Climate trends and impacts on crop production in the Koshi River basin of Nepal. Reg Environ Change. 2014;14(4):1291-1301.

5. Rost S, Gerten D, Bondeau A, et al. Agricultural green and blue water consumption and its influence on the global water system. Wat Resour Res. 2008;44:17. 
6. Fader M, Gerten D, Thammer M, et al. Internal and external greenblue agricultural water footprints of nations, and related water and land savings through trade, Hydrol. Earth Syst Sci. 2011;15:1641-1660.

7. Konar M, Dalin C, Suweis S, et al. Water for food: The global virtual water trade network. Water Resour Res. 2011;47(5):W05520.

8. Strpezek K, Boehlert B. Competition for water for the food system. Philosophical transactions the royal society B. Biological Sciences. 2010;365(1554):2927-2940.

9. Tubiello FN, Donatelli M, Rosenzweig C, et al. Effects of climate change and elevated $\mathrm{CO}_{2}$ on cropping systems:model predictions at two Italian sites. European Journal of Agronomy. 2000;13:179-189.

10. Tubiello FN, Soussana JF, Howden SM. Crop and pasture response to climate change. PNAS. 2007;104(50):19686-19690.

11. Torriani D, Calanca P, Lips M, et al. Regional assessment of climate change impacts on maize productivity and associated production risk in Switzerland. Reg Environ Change. 2007;7:209-221.

12. Supit I, Van Diepen CA, de Wit AJW, et al. Recent changes in the climatic yield potential of various crops in Europe. Agric Syst. 2010;103:683694.

13. Bocchiola D, Nana E, Soncini A. Impact of climate change scenarios on crop yield and water footprint of maize in the Po valley of Italy. Agricultural Water Management. 2013;116:50-61.

14. Nana E, Corbari C, Bocchiola D. A hydrologically based model for crop yield and water footprint assessment: study of maize in the Po valley. Agricultural Systems. 2014;127:139-149.

15. Morison JIL. Interactions between increasing $\mathrm{CO} 2$ concentration and temperature on plant growth. Plant Cell \& Environment. 1999;22(6):659-682.

16. Leuning R. A critical appraisal of a combined stomatal photosynthesis model for C3 plants. Plants Cell Environm. 1995;18:357-364.

17. Jarvis AJ, Mansfield TA, Davies WJ. Stomatal behaviour, photosynthesis and transpiration under rising $\mathrm{CO}_{2}$. Plant Cell and environment. 1999;22:639-648

18. Brouwer FM. Determination of broad-scale land use changes by climate and soils. Working Paper WP-88-007, Laxenburg, Austria: International Institute for Applied Systems Analysis; 1988.

19. Rosenzweig C, Hillel D. Climate change and the global harvest. New York, USA: Oxford University Press; 1998.

20. FAO. Adapting to Climate Change. In Unasylva. 2009;60:(231/232).

21. IPCC. Summary for Policymakers. In: Climate Change 2013:The Physical Science Basis. Contribution of Working Group I to the Fifth Assessment Report of the Intergovernmental Panel on Climate Change. Stocker TF, et al. editors. United Kingdom and New York, NY, USA Cambridge University Press, Cambridge; 2013.

22. Olesen JE, Carter TR, Diaz-Ambrona CH, et al. Uncertainties in projected impacts of climate change on European agriculture and terrestrial ecosystems based on scenarios from regional climate models. Clim Change. 2007;81(1):123-143.

23. Wheeler T, Von Braun J. Climate change impacts on global food security. Science. 2013;341(6145):508-513.

24. Karki R, Gurung A. An overview of climate change and its impact on agriculture: a review from least developing country, Nepal. International Journal of Ecosystem. 2012;2(2):19-24.

25. Immerzeel WW, Van Beek LPH, Bierkens MFP. Climate change will affect the Asian water towers. Science. 2010;328(5984):1382-1385.
26. Soncini A, Bocchiola D. Assessment of future snowfall regimes within the Italian Alps using general circulation models. Cold Regions Science and Technology. 2011;68(3):113-123.

27. World Bank. Data bank. World Development Indicators. Data by country, Nepal; 2012.

28. Nepal Agricultural Research Council, NARC. NARC's strategic vision for Agricultural Research; 2010.

29. Pokhrel DM, Thap GB. Are marketing intermediaries exploiting mountain farmers in Nepal? A study based on market price, marketing margin and income distribution analyses. Agric Sys. 2007;94(2):151-64.

30. Samriddhi. Commercialization of agriculture in Nepal. Samriddhi, The Prosperity Foundation, Kathmandu, Nepal: Discussion Paper; 2011.

31. Palazzoli I, Maskey S, Uhlenbrook S, et al. Impact of prospective climate change upon water resources and crop yield in the Indrawati basin, Nepal. Agricultural Systems. 2015;133:143-157.

32. Awasthi KD, Sitaula BK, Singh BR, et al. Land-use change in two Nepalese watersheds:GIS and geomorphometric analysis, LDD Land Degradation \& Development. 2002;13(6):495-513.

33. Rai M. Climate change and agriculture:A Nepalese case. J Agriculture and Environment. 2007;8:92-95.

34. Eriksson M, Xu JC, Shrestha AB, et al. The changing Himalayas: impact of climate change on water resources and livelihoods in the greater Himalayas; 2009.

35. Nyaupanea GP, Chhetrib N. Vulnerability to climate change of nature-based tourism in the Nepalese Himalayas. Tourism Geographies. 2009;11(1):95-119.

36. Maske S, Uhlenbrook S, Ojha S. An analysis of snow cover changes in the Himalayan region using MODIS snow products and in-situ temperature data. Climatic Change. 2011;108(1-2):391-400.

37. Shrestha AB, Aryal R. Climate change in Nepal and its impact on Himalayan glaciers. Reg Environ Change. 2011;11(1):65-77.

38. Agarwal A, Babel MS, Maskey S. Analysis of future precipitation in the Koshi River basin, Nepal. Journal of Hydrology; 2014.

39. Dulal HB, Brodnig G, Thakur HK, et al. Do the poor have what they need to adapt to climate change? A case study of Nepal Local Environ. 2010;15(7):621-35.

40. Rupa Kumar K, Sahai AK, Krishna Kumar K, et al. High resolution climate change scenario for India for the 21 st century. Curr Sci. 2006;90(3):334-345.

41. Sharma M, Dahal S. Assessment of impacts of climate change and local adaptation measures in agriculture sector and livelihoods of indigenous community in high hills of Sankhuwasabha District, Rampur, Chitwan, Nepal; 2011.

42. NAPA. National Adaptation Programme of Action (NAPA) Government of Nepal. Kathmandu, Nepal: Ministry of Environment; 2010.

43. Poudel S, Kotani K. Climatic impacts on crop yield and its variability in Nepal:do they vary across seasons and altitudes? Climatic Changem. 2013;116(2):327-355.

44. Lohani SN. Climate change in Nepal- shall we wait until bitter consequences? J Agriculture and Environment. 2007;8(3):38-45.

45. Regmi BR, Adhikari A. Human Development Report 2007. Climate change and human development-risk and vulnerability in a warming world. Country Case Study-Nepal. UNDP; 2007.

46. Manandhar S, Vogt DS, Perret SR, et al. Adapting cropping systems to climate change in Nepal:a cross-regional study of farmers' perception and practices. Reg Environ Change. 2011;11(2):335-348. 
47. Patt A, Pablo S, Hess U. How do small-holder farmers understand insurance, and how much do they want it? Evidence from Africa. Global Environ Change. 2010;20:153-161.

48. Gentle P, Maraseni TN. Climate change, poverty and livelihoods: adaptation practices by rural mountain communities in Nepal. Environmentel Sci and Pol. 2012;21:24-34.

49. Chhetri N, Chaudhary P, Tiwari PR, et al. Institutional and technological innovation: Understanding agricultural adaptation to climate change in Nepal. Applied Geography. 2012;33:142-150.

50. Rosenzweig C, Parry ML. Potential impact of climate change on world food supply. Nature. 1994;367:133-138.

51. World Bank. World Bank development report 2010: Development and climate change. Washington, DC: World Bank; 2010.

52. Agrawala S, Raksakulthai V, Van Aalst M, et al. Development and climate change in Nepal: focus on water resources and hydropower. COM/ ENV/EPOC/DCD/DAC(2003)1/FINAL, France: OECD press; 2003.

53. Karmacharya J, Shrestha A, Rajbhandari R. Climate Change Scenarios for Nepal based on Regional Climate Model RegCM3, Department of Hydrology and Meteorology Kathmandu - Nepal. Final report of the Project:"Enhancement of National Capacities in the Application of Simulation Models for Assessment of Climate Change and its Impacts on water Resources and Food and Agricultural Production"; 2007.

54. Amgain LP. Application of csm- ceres-maize model for seasonal and multi-decadal predictions of maize yield in under subtropical condition of Chitwan, Nepal. Journal of Maize Research and Development. 2015;1(1):86-97.

55. Lamsal A, Amgai LP, Giri A. Modeling the sensitivity of CERES-Rice model: An experience of Nepal. Agronomy Journal of Nepal (Agron JN). 2013;3:11-22.

56. Bocchiola D, Impact of potential climate change on crop yield and water footprint of rice in the Po Valley of Italy. Agricultural Systems. 139:223-237.
57. Buytaert W. Citizen science in hydrology and water resources: opportunities for knowledge generation, ecosystem service management, and sustainable development. Front Earth Sci. 2014.

58. Nepal R. Roles and potentials of renewable energy in less-developed economies: The case of Nepal. Renewable and Sustainable Energy Reviews. 2012;16(4):2200-2206.

59. Sharma CK. Overview of Nepal's energy sources and environment. Atmospheric Environment. 1996;30(15):2717-2720.

60. Pokharel S. Kyoto protocol and Nepal's energy sector. Energy Policy. 2007;35(4):2514-2525.

61. Chalise SR, Kansakar SR, Rees G, et al. Management of water resources and low flow estimation for the Himalayan basins of Nepal. J of Hydrol. $2003 ; 282(1-4): 25-35$.

62. Sangroula DP. Hydropower development and its sustainability with respect to sedimentation in Nepal. Journal of the Institute of Engineering. 2009;7(1):1-9.

63. Jha R. Total run-of-river type hydropower potential of Nepal. HYDRO NEPAL. 2010;7:8-13.

64. Brown S, Shrestha B. Market-driven land-use dynamics in the middle mountains of Nepal. Journal of Environmental Management. 2000;59(3):217-225.

65. Bajracharya B, Uddin K, Chettri N, et al. Understanding land cover change using a harmonized classification system in the Himalaya: a case study from sagarmatha national park, Nepal. Mountain Research and Development. 2010;30(2):143-156.

66. OXFAM. Even the Himalayas have stopped smiling: Climate change, poverty and adaptation in Nepal. Oxfam International, Lalitpur Nepal: Country Programme Office; 2009. 